\title{
WANPRESTASI PADA AKAD MURABAHAH (STUDI PUTUSAN NOMOR 1039/Pdt.G/2014/PA.Pbg).
}

\author{
Rahmadi Indra Tektona, Dyah Ochtorina Susanti, Slamet Ervin Iskliyono; Hukum Bisnis \\ Syariah, Fakultas Hukum Universitas Jember; Jl. Kalimantan 37, Jember 68121; E-mail:
} slamet.ervin21@gmail.com

\begin{abstract}
Abstrak
Jual beli merupakan suatu hal yang lumrah atau lazim dilakukan. Sama halnya dengan jual beli dalam bank syariah menggunakan akad murabahah. Yang sering terjadi dalam menyicil pembayaran adalah terjadinya ingkar janji/wanprestasi. Artikel ini menganalisis dikeluarkannya Putusan Pengadilan Agama Purbalingga Nomor 1039/Pdt.G/2014/PA.Pbg terkait dengan wanprestasi pada akad murabahah. Dimana Nasabah membeli sebuah truck dari Bank Syariah menggunakan akad murabahah yang pembayarannya dicicil selama 4 tahun yang dimana nasabah tersebut menunggak pembayaran sehingga pihak bank syariah menggugat melalui Pengadilan Agama Purbalingga. Diputuskan oleh Majelis Hakim bahwa Nasabah terbukti melakukan ingkar janji/wanprestasi terhadap akad murabahah serta diwajibkan membayar ganti rugi. Artikel ini menganalisis dari segi ilmu hukum dasar, Hukum Perdata, hingga Hukum Islam. Hasilnya terdapat denda dalam akad murabahah yang dibuat kedua belah pihak yang dilarang oleh Islam serta belum adanya Pasal dalam Undang-Undang Nomor 21 Tahun 2008 tentang Perbankan Syariah yang mengatur tentang denda maupun ganti rugi menurut hukum Islam.
\end{abstract}

Kata Kunci: Wanprestasi, Akad Murabahah, Putusan

\section{Abstract}

Commercial transaction is common activity that exists nowadays. Including the Islamic Banks, that apply Murabaha Agreement in its transaction process. The Default/Wanprestasi frequently happens in the instalments of the payment in it. This research analyzes the issuance of the Verdict of Purbalingga Religious Court Number 1039/Pdt.G/2014/PA.Pbg related to breach of Murabaha contract. In which the customer buys a truck from an Islamic Bank by using Murabaha Agreement. The payment must be repaid in 4 years, but he arrears that, as the consequence, the Bank sues him to Purbalingga Religious Court. It was decided by the Panel of Judges that he was proven to do wanprestasi and required to pay compensation for his action. This case is analyzed through the perspective of basic legal science, civil law, and Islamic law. The results show that there are fines in the Murabaha contract that are prohibited by Islam and there is no article in the Constitution Number 21 year 2008 concerning to the Islamic Banking that regulates the fines or compensation based on the Islamic law.

Keywords: Default, Murabahah Agreement, Verdict

\section{PENDAHULUAN}

\section{Latar Belakang}

Perbankan di Indonesia banyak mengalami sengketa, tak lain halnya dengan perbankan syariah yang juga banyak mengalami sengketa ekonomi syariah, namun untuk sengketa ekonomi syariah kompetensi absolut berada di lingkup Peradilan Agama. Berbeda dengan Perbankan Konvensional dimana kompetensi absolut berada di Peradilan Negeri. Kompetensi Absolut Peradilan Agama diatur dalam Pasal 2 Undang-Undang Nomor 7 Tahun 1989 yang telah diubah dengan Undang-Undang Nomor 3 Tahun 2006 dimana kompetensi absolut peradilan agama yaitu salah satu peradilan yang pelaksanaan kekuasaan kehakiman bagi masyarakat yang beragama Islam yang diatur dalam Pasal 49 
ayat (1) Undang-Undang Nomor 3 Tahun 2006, yaitu bidang perkawinan, waris, wasiat, hibah, wakaf, zakat, infak, sedekah, dan ekonomi syariah.

Akad pembiayaan murabahah merupakan akad yang sering digunakan dalam akad jual beli dalam perbankan syariah. Pada Prinsipnya, akad murabahah merupakan akad jual beli, ketika ada permintaan dari nasabah, kemudian bank membeli pesanan yang sesuai dengan nasabah, lalu bank menjual kepada nasabah dengan harga pokok dan margin keuntungan yang disepakati bersama. ${ }^{1}$

Salah satu kasus yang terjadi adalah cedera janji/ingkar janji yang dalam bahasa hukum biasa dikenal dengan wanprestasi. Terjadi pada salah satu sengketa ekonomi syariah yang diputus oleh pengadilan agama Purbalingga dengan nomor perkara 1039/Pdt.G/2014/PA/Pbg. Gugatan diajukan oleh penggugat kepada ketua pengadilan agama yang berwenang, yang memuat tuntutan hak yang ada di dalamnya mengandung sengketa dan merupakan dasar landasan pemeriksaan perkara dan pembuktian kebenaran suatu hak tertentu dari pihak tertentu. ${ }^{2}$ Pada pokok perkara cedera janji/ingkar janji (wanprestasi) yang dilakukan oleh pihak Tergugat I (yang dalam putusan tidak disebutkan identitasnya), atas persetujuan Tergugat II sebagai istri (yang dalam putusan tidak disebutkan identitasnya) melawan Penggugat yaitu PT. Bank Pembiayaan Rakyat Syariah (BPRS) Buana Mitra Perwira.

Tergugat I, atas persetujuan Tergugat II berdasarkan Akad Murabahah nomor : 51/656-1/10/12 menerima fasilitasi piutang murabahah dari Penggugat yaitu PT. Bank Pembiayaan Rakyat Syariah Buana Mitra Perwira sebesar Rp.136.000.000,- (seratus tiga puluh enam juta rupiah), dengan perhitungan harga perolehan Rp.85.000.000,- (Delapan puluh lima juta rupiah) ditambah margin sebesar Rp.51.000.000,- (lima puluh satu juta rupiah) untuk pembelian sebuah Truck Dump/Mobil barang dengan tujuan pembelian untuk sarana modal kerja pengangkutan. Jangka waktu piutang murabahah tersebut dilakukan selama 4 tahun sejak tanggal 4 Oktober 2012 sampai dengan 4 Oktober 2016. Namun pada pertengahan jalan, tergugat tidak dapat membayar angsuran sesuai dengan perjanjian, sehingga penggugat melayangkan beberapa kali surat peringatan dan somasi kepada tergugat. Sampai pada saat gugatan tertanggal 19 Juni 2014 ini diajukan, tergugat masih belum melunasi angsuran yang ditetapkan. Pada putusan yang dijatuhkan pada tanggal 25 Februari 2015, dalam konvensi, hakim mengabulkan sebagian gugatan dari penggugat, dan menolak selebihnya gugatan penggugat, dan dalam rekonvensi menolak gugatan penggugat rekonvensi seluruhnya.

\footnotetext{
${ }^{1}$ Darsono, Ali Sakti, Ascarya, dkk. Perbankan Syariah di Indonesia: Kelembagaan dan Kebijakan Serta Tantangan ke Depan. Jakarta: Rajawali Pers, 2017, h. 222.

2 Zulkarnaen, Dewi Mayaningsih. Hukum Acara Peradilan Agama di Indonesia (Lengkap dengan Sejarah dan Kontribusi Sistem Hukum terhadap Perkembangan Lembaga Peradilan Agama di Indonesia). Bandung: Pustaka Setia, 2017, h.173.
} 


\section{METODE PENELITIAN}

Metode penelitian yang digunakan dalam karya tulis ilmiah ini adalah metode penelitian hukum. Penelitian hukum dilakukan untuk menemukan apa hukumnya mengenai suatu fakta tertentu dan penelitian hukum untuk pengembangan ilmu hukum. Penelitian hukum untuk menemukan hukum mengenai suatu fakta tertentu menggunakan peraturan-peraturan hukum dan putusan-putusan pengadilan untuk memperoleh jawaban atas isu yang diajukan.

\section{PEMBAHASAN}

\section{A. Dasar Pertimbangan Hakim (Ratio Ddecidendi) dalam Mengabulkan Gugatan} Sebagian dan Menolak Selebihnya dalam Putusan Nomor 1039/Pdt.G/2014/PA.Pbg

Asal mula perkara ini diawali oleh seorang nasabah yang mengajukan pembiayaan murabahah kepada salah satu bank syariah di kota Purbalingga untuk pembelian sebuah kendaraan jenis truck yang nantinya akan digunakan untuk kegiatan usaha pengangkutan oleh nasabah tersebut. Fasilitas Pembiayaan yang diberikan oleh Bank Syariah tersebut adalah sebesar Rp. 136.000.000,- dengan harga perolehan Rp.85.000.000,- ditambah dengan margin sebesar Rp.51.000.000,-. Jangka waktu yang piutang murabahah yaitu selama 4 (empat) tahun yaitu sejak tanggal 4 Oktober 2012 sampai dengan tanggal 4 Oktober 2016. Dengan menggunakan jaminan yaitu tanah pekarangan beserta bangunan berdasarkan sertipikat hak milik atas nama Istri dari nasabah dengan luas $427 \mathrm{~m}^{2}$, yang terletak di Kabupaten Purbalingga, Provinsi Jawa Tengah.

Pembiayaan sudah berjalan beberapa bulan, suatu ketika nasabah tersebut mengunggak angsuran yang telah disepakati oleh kedua belah pihak. Sehingga pihak bank tersebut beberapa kali melayangkan surat peringatan hingga somasi. Namun tidak ditanggapi oleh nasabah tersebut sehingga pihak Bank Syariah mengajukan gugatan ke Pengadilan Agama setempat yaitu Pengadilan Agama Purbalingga. Pihak Bank Syariah sudah beberapa kali memberikan kesempatan kepada pihak nasabah untuk melunasi tunggakan, namun sampai gugatan tersebut diajukan, masih tidak ada tanggapan dari pihak nasabah.

Pertimbangan Hakim (Ratio Decidendi) merupakan alasan-alasan hukum yang digunakan oleh hakim untuk mencapai suatu putusan. ${ }^{3}$ Berikut adalah pertimbangan hakim dalam kompetensi absolut dan kompetensi relatif. Majelis Hakim melakukan pertimbangan dengan langkah awal yaitu memeriksa kompetensi absolute dan kompetensi relative dalam perkara tersebut. Majelis Hakim menyimpulkan bahwa perkara tersebut adalah wewenang Pengadilan Agama Purbalingga. Pertimbangan tersebut merupakan pertimbangan hukum yang dilakukan oleh hakim terhadap Kompetensi Absolut dan Kompetensi Relatif dari suatu perkara. Kompetensi Absolut atau kewenangan absolut yang dapat juga dinamakan atribusi "kekuasaan", yaitu semua ketentuan yang termasuk dalam kewenangan atau kekuasaan dari berbagai macam jenis pengadilan. ${ }^{4}$ Kompetensi Absolut dalam hal ini adalah wewenang mutlak

\footnotetext{
3 Peter Mahmud Marzuki. Penelitian Hukum. Jakarta: Prenada Media Kencana, 2006, h.119.

4 Subekti. Hukum Acara Perdata. Bandung : Binacipta, 1989, h. 23.
} 
dari pengadilan yang berhak untuk mengadili berdasarkan Pasal 49 Undang-Undang Nomor 3 Tahun 2006 Perubahan atas Undang-Undang Nomor 7 Tahun 1989 Pengadilan Agama bertugas dan berwenang memeriksa, memutus dan menyelesaikan perkara di tingkat pertama antara orang-orang yang beragama islam di bidang: perkawinan, waris, wasiat, hibah, wakaf, zakat, infaq, shadaqah, dan ekonomi syariah. Kompetensi Relatif yaitu atau dapat disebut "distribusi kekuasaan" yaitu semua ketentuan tentang pembagian kekuasaan dari tiap-tiap jenis pengadilan tersebut. ${ }^{5}$ Kompetensi Relatif atau Kekuasaan Relatif antara Pengadilan-Pengadilan Negeri dapat ditemukan pengaturannya dalam pasal 118 H.I.R, yaitu pasal yang mengatur terkait pengajuan gugatan yang menentukan dimana gugatan harus diajukan. Pasal tersebut mengatur bahwa gugatan diajukan berdasarkan wilayah hukum tergugat.

Pertimbangan selanjutnya mengenai pokok sengketa dalam perkara tersebut apakah sah secara hukum Akad Murabahah antara Penggugat dan Tergugat Nomor : 51/656-1/10/12 tertanggal 4 Oktober 2012 yang dibuat antara Penggugat dengan Para Tergugat yang sudah di waarmerking atau telah dilegalisasi oleh salah satu notaris di Purbalingga SRI WACHYONO, SH, MH, M.Kn., dan apakah Para Tergugat telah cidera janji / ingkar janji / wanprestasi terhadap Akad Murabahah tersebut dengan merugikan pihak Penggugat yang perincian dalam dalil gugatan per Mei 2014 sebagai berikut:

Pokok harga perolehan / pembiayaan

Margin Keuntungan

Denda keterlambatan (Akad Pasal 5 ayat 4 )

Biaya Kuasa Hukum ( Akad Pasal 5 ayat 2 )

Kewajiban Para Tergugat
: Rp. 66.907.812,-

: Rp. 12.519.685,-

:Rp. 660.000,-

: Rp. 8.000.000,-

: Rp. 88.087.497,-

Terkait dengan alat bukti, Penggugat telah mengajukan banyak bukti-bukti yang berupa fotokopi dan telah dicocokkan oleh majelis hakim dan merupakan alat bukti yang sah di persidangan sehingga hakim memiliki pertimbangan yaitu bahwa, buktibukti yang diajukan oleh Penggugat dari bukti P.1 sampai dengan P.14 seluruhnya dalam bentuk foto copy yang kemudian telah dicocokkan oleh Majelis Hakim di persidangan dan ternyata sesuai dengan aslinya serta bermaterai cukup sehingga dapat diterima sebagai alat bukti yang sah di persidangan. Semua alat bukti dari bukti P.1 sampai dengan P.8 adalah akta otentik yang tidak dibantah oleh pihak lawan, maka sesuai Pasal 165 HIR merupakan bukti sempurna (voilledig) dan mengikat (bindende), sedangkan bukti P.9 sampai dengan P.11 berupa surat Somasi yang tidak dibantah pihak Tergugat. Adapun bukti P.12 berupa Akta sepihak maka mengikat terhadap pihak yang bertanda tangan, sedangkan bukti P.13 dan P.14 berupa tulisan dari pembukuan sehingga sesuai pasal 167 HIR jo. Pasal 7 KUHD, mempunyai kekuatan pembuktian bebas.

${ }^{5}$ Ibid. 
Alat bukti yang diajukan oleh Penggugat merupakan alat bukti yang otentik dan kuat sehingga pihak tergugat tidak dapat membantah dengan dalilnya karena alat bukti tersebut telah diakui keabsahannya oleh majelis hakim. Serta semua alat bukti yang diajukan merupakan alat bukti yang sangat penting dalam perkara ini. Kemudian menurut Tergugat, PT. Bank Pembiayaan Rakyat Syariah (BPRS) Buana Mitra Perwira, lalai dalam memperhitungkan ketidakmampuannya dalam menyalurkan pembiayaan baik dari segi ekonomi makro maupun SDM sebagai pengelolaan pembiayaan. Menurut Tergugat hal tersebut menunjukkan bank tidak memperhatikan prinsip prudential banking practice atau prudencial banking principle sebagaimana di atur dalam undang- undang perbankan dan Peraturan Bank Indonesia, sehingga ketidakmampuan Tergugat I mengelola keuangan yang diberikan Penggugat kepada Tergugat I adalah mutlak kesalahan dari Penggugat sehingga tidak dapat menyalahkan kepada Tergugat I, karena tidak memberi keuntungan kepada Penggugat atas murabahah tersebut. Alat Bukti yang digunakan Tergugat tidak dapat dibenarkan oleh hukum ekonomi syariah karena Tergugat I menafsirkan kutipan dari buku maupun bunyi pasal 1238 Kitab Undang - Undang Hukum Perdata secara tidak tepat dan bukan ahli yang memperkuat dalil tersebut. Sehingga Majelis Hakim mengesampingkan bukti-bukti T.1 dan T.2.

Setiap orang yang mendalilkan bahwa ia mempunyai sesuatu hak, atau, guna meneguhkan haknya sendiri maupun membantah suatu hak orang lain, menunjuk pada suatu peristiwa, diwajibkan membuktikan adanya hak atau peristiwa tersebut. ${ }^{6}$ Membuktikan ialah meyakinkan hakim tentang kebenaran atau dalil-dalil yang dikemukakan dalam suatu persengketaan atau perselisihan. ${ }^{7}$ Menurut Pasal 164 HIR (Herzien Inlandsch Reglement) terdapat 5 jenis alat bukti yang terdiri atas:
a. Bukti tulisan/surat;
b. Saksi-saksi
c. Persangkaan
d. Pengakuan
e. Sumpah

Karena membuktikan itu adalah meyakinkan hakim tentang kebenaran dalil-dalil yang dikemukakan, maka dengan sendirinya segala apa yang dilihat sendiri oleh hakim di muka sidang tidak usah dibuktikan. ${ }^{8}$

Pembuktian yang dilakukan oleh pihak penggugat dapat dikatakan kuat, karena dapat dilihat bahwa alat bukti yang digunakan merupakan bukti tulisan/ surat yang diakui keasliannya sehingga merupakan alat bukti yang kuat. Sedangkan pembuktian yang dilakukan oleh tergugat hanya berupa tulisan buku dan bunyi pasal $1238 \mathrm{KUH}$ Perdata yang tidak dapat memperkuat dalil bantahannya sehingga alat bukti T.1 dan T.2 dikesampingkan oleh hakim.

\footnotetext{
${ }^{6}$ Lihat Pasal 1865 Kitab Undang-Undang Hukum Perdata

7 Subekti. Op.Cit. h. 78

${ }^{8}$ Ibid. h. 82
} 
Hakim berpendapat berdasarkan fakta hukum angka 3, yaitu ternyata para Tergugat lalai tidak membayar angsuran sesuai dengan jumlah yang telah ditetapkan sejak bulan Juli 2013 sampai Desember 2013 dan setelah itu Para Tergugat tidak membayar angsuran sama sekali sampai gugatan diajukan dan fakta hukum angka 4 yaitu Penggugat telah 3 kali melayangkan Surat Peringatan(SP1-SP3) kepada Para Tergugat agar dapat membayar tunggakan angsuran namun sampai penggugat mengeluarkan somasi dan sampai gugatan ini diajukan, Para Tergugat tidak membayar angsuran kewajibannya kepada Penggugat. ${ }^{9}$ Perbuatan tergugat dapat dikatakan bahwa telah sesuai dengan ketentuan mengenai wanprestasi sebagaimana diuraikan di atas, sehingga para Tergugat harus dinyatakan telah melakukan perbuatan cidera janji/ ingkar janji/ wanprestasi terhadap Akad Jual Beli Murabahah Nomor : --- tertanggal 4 Oktober 2012 yang merugikan Penggugat.

Kerugian yang ditimbulkan oleh tergugat menurut perhitungan penggugat yang dirugikan secara materiil yaitu sesuai dengan Akad Pembiayaan Jual Beli Murabahah Nomor : --- tertanggal 4 Oktober 2012 yang perinciannya per Mei 2014 adalah sebesar Rp. 88.087.497,--. Menurut Hakim total kerugian tersebut diperhitungkan secara tidak tepat dan tidak dapat dibenarkan karena tidk sesuai dengan nilai kerugian riil (real loss) yang pasti dialami (fixed cost) dalam transaksi tersebut dan bukan kerugian yang diperkirakan akan terjadi (potential loss) karena adanya peluang yang hilang (opportunity loss atau al-furshah al-dha-i'ah (pasal 6 Fatwa Dewan Syari'ah Nasional Nomor 43/Dsn- Mui/Viii/2004 tanggal 11 Agustus 20014 M Tentang Ganti Rugi (Ta'widh), dalam Ketentuan Umum).

Pertimbangan lain yaitu bahwa besarnya denda keterlambatan sesuai dengan peraturan perusahaan (bank) yang dituntut sebesar Rp.600.000,- untuk dana qardhul hasan ini sesuai dengan ketentuan pasal 5 ayat 4 akad, maka dapat dikabulkan

Biaya kuasa hukum yang diperhitungkan Penggugat sebesar Rp.8.000.000,menurut hakim meskipun biaya kuasa hukum dicantumkan di dalam akad tetapi tidak ditentukan biaya kuasa hukumnya. Oleh karena itu Hakim berpendapat berdasakan asas Taswiyah (kesetaraan) dan transparansi dalam akad syariah, maka Biaya Kuasa Hukum sebesar Rp. 8.000.000,- tersebut merupakan jumlah yang tidak adil dan tidak transparan karena bisa diisi dengan jumlah berapapun menurut harga yang disepakati oleh Penggugat dengan kuasa hukumnya kemudian dibebankan kepada pihak Tergugat seluruhnya, padahal pihak Tergugat jika ia kalah juga dibebankan untuk membayar biaya perkara. Oleh karena itu menurut hakim, lebih baik biaya kuasa hukum tersebut dipikul kedua belah pihak masing-masing seperduanya yaitu Rp.4.000.000,- agar lebih adil.

Menurut Majelis Hakim, kerugian Materiil yang harus dibayar oleh Para Tergugat kepada Penggugat sesuai perhitungan per Mei 2014 adalah sebagai berikut:

Biaya Kuasa Hukum (Akad Pasal 5 ayat 2 ) : Rp. 4.000.000,-

Total kewajiban Para Tergugat $\quad$ : Rp. 80.899.797,-

${ }^{9}$ Lihat Putusan Nomor 1039/Pdt.G/2014/PA.Pbg. h.25 
Tahap setelah hakim melakukan pertimbangan, yaitu hakim menerapkan hukumnya berdasarkan undang-undang yang ada, serta megabulkan atau tidaknya dari gugatan yang diajukan oleh penggugat maupun penggugat rekonvensi. Berikut adalah penerapan yang dilakukan oleh hakim beserta mengkabulkan gugatan atau tidaknya:

Berdasarkan pada pertimbangan tersebut, maka hakim berpendapat bahwa petitum angka 4 dapat dikabulkan sebagian dengan menyatakan Para Tergugat telah melakukan perbuatan cidera janji/ wanprestasi terhadap Akad Pembiayaan Jual Beli Murabahah Nomor : 51/656-1/10/12 tertanggal 4 Oktober 2012 yang merugikan Penggugat, yaitu berupa kerugian materiil sebesar Rp. 80.899.797,- (delapan puluh juta delapan ratus sembilan puluh sembilan ribu tujuh ratus sembilan puluh tujuh rupiah). Dikatakan sebagian karena tidak memenuhi total kerugian dalam gugatan yaitu sebesar Rp.88.087.497,- (delapan puluh delapan juta delapan puluh tujuh empat ratus sembilan puluh tujuh rupiah) ${ }^{10}$

Petitum angka 4 dikabulkan sebagian dikarenakan tidak memenuhi gugatan menyebabkan petitum angka 5 juga dikabulkan sebagian oleh hakim dengan menghukum Para Tergugat untuk membayar kerugian materiil kepada Penggugat sebesar Rp. 80.899.797,-,-( delapan puluh delapan juta delapan ratus sembilan puluh sembilan ribu tujuh ratus sembilan puluh tujuh rupiah) ${ }^{11}$

Hakim juga tidak mengabulkan petitum angka 1 dan 2 karena berdasarkan fakta pada angka 2 di atas, ternyata obyek yang dimohonkan sita jaminan (Conservatoir Beslaag) oleh Penggugat telah diletakkan Hak tanggungan yang pemegangnya adalah Penggugat sendiri, sehingga permohonan conservatoir beslaag yang diajukan oleh Penggugat tidak beralasan hukum, maka dari itu Hakim telah mengeluarkan Penetapan Sela Nomor : 1039/ Pdt.G/2014/PA. Pbg., tanggal 07 Januari 2015, yang amarnya menolak permohonan Penggugat untuk meletakkan sita jaminan. Sehingga berdasarkan pada pertimbangan-pertimbangan tersebut, hakim menolak gugatan Penggugat selain dan selebihnya.

Penggugat Rekonvensi sama sekali tidak mengajukan bukti-bukti untuk menguatkan dalil gugatan rekonvensi tersebut dan sebaliknya telah terbukti sebagai fakta hukum angka 5 dalam perkara konvensi bahwa Tanah Hak Milik berikut bangunan Sertipikat Nomor: ---, Luas 427 M2, terletak di Kabupaten Purbalingga atas nama hak milik Tergugat II (Tergugat II) telah diletakkan Hak Tanggungan dengan Pemegang Hak : PT. Bank Pembiayaan Rakyat Syariah Buana Mitra Perwira (Penggugat) sebagai jaminan pelunasan utang para Tergugat kepada Penggugat berdasarkan akad Jual Beli Murabahah Nomor :--- tertanggal 4 Oktober 2012. Gugatan Penggugat Rekonvensi bertujuan untuk membatalkan hak tanggungan terhadap objek tersebut, namun hakim berpendapat bahwa gugatan tersebut tidak beralasan karena objek tersebut merupakan jaminan yang digunakan Penggugat rekonvensi untuk mendapat pembiayaan murabahah.

${ }^{10} \mathrm{Ibid}$. h.5

${ }^{11}$ Ibid. 
Tidak adanya Pasal ataupun Undang-Undang Syariah yang mengatur secara khusus tentang sanksi-sanksi atas perbuatan hukum dalam bidang syariah khususnya ingkar janji dalam bidang syariah sehingga Hakim mempertimbangkan dengan Kitab UndangUndang Hukum Perdata. Sedangkan dalam hukum islam juga tidak terdapat hukum yang tegas mengatur tentang ingkar janji. Dalam Al-Qur'an Surah Al-Maidah ayat 89 dijelaskan bahwa hukuman sebagai penebus dosa yaitu memberi makan sepuluh orang miskin, memberi mereka pakaian, atau jika tidak sanggup maka melakukan puasa selama 3 hari. Ataupun dapat juga menggunakan teori Jawabir dan Jawazir. Jawabir artinya adalah sebagai penebus siksa akhirat sedangkan Jawazir adalah Pencegah terjadinya perbuatan untuk terulang kembali.12 Jawabir sebagai penebus dosa seperti halnya dengan Qur'an Surah Al-Maidah ayat 89 yang dapat dijadikan sebagai jawabir atau penebus dosa. Sedangkan untuk Jawazir sebagai pencegahnya belum ada yang mengatur terkait ancaman melakukan ingkar janji. Karena berhutang merupakan hal yang wajar bagi setiap orang, namun tidak semua orang menerapkan hutang harus dibayar lunas karena hutang dibawa sampai orang yang berhutang tersebut meninggal dunia. Tidak adanya sanksi yang dapat mencegah terjadinya ingkar janji yang dapat menyebabkan kerugian terhadap orang yang meminjamkan uang menyebabkan banyaknya orang yang tidak berhati-hati dan sehingga salah memilih akad yang harus digunakan, akad kerjasama seperti musyarakah dan mudharabah dapat menjadi solusi dalam melakukan kerja sama atau bisnis usaha.

Hukum Islam melarang memberikan denda terhadap orang yang sedang mengalami kesulitan yang dalilnya terdapat dalam QS. Al-Baqarah ${ }^{13}$, khususnya dalam putusan halaman 3(tiga) terdapat penerapan denda terhadap nasabah yang tercantum dalam Akad Murabahah pasal 5 ayat 4 . Sehingga membuat Akad tersebut tidak sesuai dengan hukum islam yang sebenarnya.

\section{B. AKIBAT HUKUM BAGI PARA PIHAK DENGAN KELUARNYA PUTUSAN NOMOR 1039/Pdt.G/2014/PA.Pbg}

Perkara dalam putusan ini diawali dengan perjanjian yang dilakukan oleh Penggugat dan Tergugat yaitu Pihak Bank Syariah Sebagai Penggugat dan Pihak Nasabah sebagai Tergugat I berdasarkan perijinan dari Tergugat II selaku istri dari Tergugat I. Perjanjian yang dilakukan adalah perjanjian dalam bentuk Akad Murabahah atau Akad Jual Beli. Saat Akad sudah berjalan, dalam pertengahan pembayaran, Tergugat selaku nasabah menunggak pembayaran rutin sehingga Penggugat melayangkan surat peringatan dari surat peringatan I (SP1) sampai surat

12 https://www.eramuslim.com/berita/analisa/dalil-bahwa-syariah-islam-sebagai-jawabirpenebus-siksa-akhirat-jawazir-pencegah-terjadinya-tindak-kriminal-yang-baru-terulang-

kembali.html diakses pada tanggal 10 Oktober 2019.

${ }^{13}$ Lihat QS. Al-Baqarah ayat 279-280 yang terjemahannya sebagai berikut:

"Apabila orang yang kamu utangi itu mengalami kesulitan ekonomi, tidak punya uang untuk melunasinya, maka tundalah tagihannya sampai kondisi keuangannya membaik dan mampu melunasi utangnya. Bila kalian bersedekah kepadanya dengan tidak menagih utangnya atau membebaskan sebagian utangnya, itu lebih baik bagi kalian jika kalian mengetahui keutamaan tindakan

kalian

itu

di

sisi

Allah" 
peringatan III (SP3) hingga Penggugat telah melayangkan somasi. Namun sampai gugatan diajukan tidak ada itikad tergugat untuk melunasi tunggakan pembayaran akad. Sehingga Pihak bank Syariah melayangkan gugatannya. Dalam persidangan telah dilakukan mediasi namun tidak berhasil sehingga dilanjutkan melalui putusan hakim dimana para pihak harus membuktikan dalil mereka masing-masing. Tergugat terbukti melakukan cidera janji atau wanprestasi terhadap akad murabahah dengan Penggugat dan diharuskan membayar ganti rugi sebesar Rp.80.899.797,- (delapan puluh juta delapan ratus sembilan puluh sembilan ribu tujuh rauts sembilan puluh tujuh rupiah) kepada Penggugat.

Akibat hukum adalah akibat yang timbul karena suatu peristiwa hukum. ${ }^{14}$ Akibat hukum dapat berupa: 15

a. Lahirnya, berubahnya atau lenyapnya suatu keadaan hukum.

b. Lahirnya, berubahnya atau lenyapnya suatu hubungan hukum antara dua atau lebih subyek hukum dimana hak dan kewajiban pihak yang satu berhadapan dengan hak serta kewajiban pihak lain.

c. Lahirnya suatu sanksi apabila dilakukan tindakan yang melawan hukum.

Akibat hukum ini diakibatkan oleh suatu tindakan yang dikehendaki pihak yang melakukan perbuatan hukum dan diatur oleh undang-undang dan pihak tersebut harus menanggung akibatnya. Akibat hukum tersebut tidak hanya berlaku pada tergugat, namun pihak penggugat juga mendapatkan akibat hukum dari peristiwa hukum yang terjadi. Soeroso dalam bukunya menjelaskan lebih lanjut terkait perbuatan hukum atau tindakan hukum sebagai sebab lahirnya suatu akibat hukum yakni terjadinya suatu perbuatan hukum baru terdapat suatu pernyataan kehendak dari subyek hukum yakni manusia. Dalam pernyataan kehendak diperlukan adanya hal hal sebagai berikut: 16

a. Kehendak orang tersebut untuk bertindak dengan menerbitkan atau menimbulkan akibat yang diatur oleh hukum.

b. Pernyataan kehendak, pada asasnya tidaklah terikat pada bentuk-bentuk tertentu serta tidak ada suatu pengecualian, sebab pernyataan kehendak dapat terjadi secara:

1. Pernyataan kehendak secara tegas yakni suatu pernyataan keinginan manusia yang dapat dilakukan dengan:

a. Tertulis, dapat dikerjakan oleh subyek hukum dengan cara ditulis sendiri dan atau ditulis oleh pejabat tertentu dan ditandatangani oleh pejabat tersebut.

b. Mengucap kata atau secara verbal, yakni suatu pernyataan kehendak ini cukup dinyatakan dengan mengucap kata setuju.

c. Isyarat, pernyataan kehendak dapat dilakukan secara tegas dengan isyaratnya, misalnya menganggukkan kepala tanda setuju, menggelengkan

\footnotetext{
14 Soeroso. Pengantar Ilmu Hukum. Jakarta: Sinar Grafika, 2000, h.296.

15 Ibid.

16 Ibid, h. 291-292.
} 
kepala merupakan bentuk pernyataan menolak, mencibirkan bibir, mengerlikan mata ataupun mengangkat alis merupakan suatu bentuk pernyataan kehendak melalui isyarat.

2. Pernyataan kehendak yang dilakukan secara diam-diam dapat diketahui dari sikap maupun perbuatan, misalnya sikap diam yang ditunjukkan seseorang dalam forum rapat berarti tanda setuju.

3. Perbuatan hukum, terdiri atas:

a. Perbuatan hukum sepihak yakni perbuatan hukum yang dilakukan oleh satu pihak saja dan menimbulkan hak serta kewajiban oleh satu pihak pula. Misalnya Pemberian hibah sesuatu benda (Pasal 1666 Kitab UndangUndang Hukum Perdata)

b. Perbuatan hukum dua pihak yakni suatu perbuatan hukum yang dilakukan oleh dua pihak dan menimbulkan hak-hak serta kewajiban-kewajiban bagi kedua belah pihak atau merupakan suatu timbal balik antar keduanya. Misalnya perjanjian sewa-menyewa (Pasal 1457 Kitab Undang-Undang Hukum Perdata).

Salah satu Akibat Hukum yaitu lahirnya sanksi. Sanksi dalam bentuk ganti rugi sesuai dengan Fatwa Dewan Syari'ah Nasional Majelis Ulama Indonesia (DSN-MUI) dengan Nomor 43/DSN-MUI/VIII/2004 atau Pasal 1243 Kitab Undang- Undang Hukum Perdata.

Hubungan hukum antara Tergugat dan Penggugat dilakukan dengan melakukan perjanjian dalam bentuk Akad Murabahah yang disetujui oleh kedua belah pihak. Perbuatan Hukum sendiri merupakan perbuatan yang menimbulkan hak dan kewajiban antara dua belah pihak atau lebih yang dimana akibat hukum dari perbuatan hukum tersebut daitur oleh hukum dan dikehendaki oleh pihak yang melakukan perbuatan hukum. ${ }^{17}$ Perbuatan hukum tersebut menimbulkan suatu hak dan kewajiban bagi para pihak, dimana pihak Penggugat berkewajiban untuk memberikan pembiayaan Murabahah kepada tergugat dan berhak mendapatkan pembayaran angsuran dari tergugat. Sedangkan tergugat berkewajiban untuk membayar angsuran kepada Penggugat dan Berhak mendapatkan Pembiayaan Murabahah dari Penggugat.

Ketika hubungan hukum sudah berjalan, terjadilah sebuah peristiwa hukum dimana Tergugat melakukan suatu perbuatan hukum yaitu tidak membayar secara rutin angsuran yang telah disepakati bersama. Penggugat sudah beberapa kali mengeluarkan surat peringatan hingga somasi namun sampai perkara tersebut disidangkan, tergugat tidak dapat menyelesaikan kewajibannya terhadap penggugat. Peristiwa hukum yang dilakukan tergugat tersebut dikategorikan sebagai ingkar janji atau dalam bahasa hukum dikenal sebagai Wanprestasi. Karena akibat perbuatan ingkar janji/ wanprestasi tersebut penggugat mengalami kerugian secara materiil yang sesuai dengan Akad Murabahah yang disepakati bersama tersebut sebesar Rp.

17 Ibid, h.291. 
88.087.497,- . Perbuatan Hukum yang dilakukan tergugat tersebut menimbulkan akibat hukum yang tidak hanya berlaku pada Tergugat saja melainkan kedua belah pihak.

Perkara ini dapat dikategorikan sebagai perbuatan hukum dua pihak antara Penggugat dan Tergugat. Sedangkan Perbuatan hukum yang dilakukan oleh Tergugat merupakan perbuatan yang dilarang oleh hukum (onrechtmatige daad) Perbuatan yang dilarang oleh hukum atau perbuatan melawan hukum yang lazimnya disebut onrechtmatige daad adalah sesuatu perbuatan yang menimbulkan kerugian kepada orang lain dan mewajibkan salah satu pihak yang bersalah untuk mengganti kerugian yang ditimbulkannya. ${ }^{18}$ Aturan hukum yang mengatur tentang perbuatan melawan hukum atau onrechtmatige daad termuat dalam pasal 1365-1380 Kitab Undang-Undang Hukum Perdata.

Akibat hukum dalam perkara ini berdasarkan Pasal 1243 KUH Perdata yaitu ganti rugi. Serta berdasarkan Fatwa Dewan Syariah Nasional Majelis Ulama Indonesia (DSN-MUI) Nomor 43/DSN-MUI/VIII/ 2004 tentang Ganti Rugi (Ta'widh). Ganti rugi diberikan kepada pihak yang dirugikan akibat tidak terpenuhinya suatu perjanjian yang dalam hal ini pihak tergugat tidak membayar secara rutin Akad Murabahah terhadap pihak penggugat yang dimana pihak tergugat tidak memenuhi perjanjian yang disepakati dengan penggugat. Dalam agama islam sendiri, akibat dari wanprestasi/ ingkar janji yaitu dosa yang membuatnya sengsara di akhirat karena nantinya janji-janji akan dimintai pertanggungjawabannya. ${ }^{19}$ Sehingga dalam kehidupan dunia harus berhati-hati dalam melakukan janji agar tidak berdosa.

Berikut adalah akibat yang timbul atas keluarnya putusan nomor 1039/Pdt.g/2014/PA.Pbg dalam perkara ini:

Hakim Menimbang dalam konvensi dan rekonvensinya, bahwa karena Pihak Tergugat Konvensi/Penggugat Rekonvensi adalah pihak yang kalah, maka berdasarkan pasal 181 HIR biaya yang timbul dalam perkara tersebut dibebankan kepada para Tergugat Konvensi/Penggugat Rekonvensi. Mengabulkan gugatan Penggugat untuk sebagian. Menyatakan sah secara hukum Akad Murabahah Nomor : --- tertanggal 4 Oktober 2012 yang dibuat antara Penggugat dengan Para Tergugat yang di waarmerking oleh Sri Wachyono, S.H., M.H., M.Kn., Notaris di Purbalingga. Menyatakan Para Tergugat telah melakukan perbuatan cidera janji/ ingkar janji/wanprestasi terhadap Akad Murabahah Nomor : --- tertangga 14 Oktober 2012 yang telah merugikan Penggugat, yaitu berupa kerugian materiil sebesar Rp. 80.899.797,- (delapan puluh juta delapan ratus sembilan puluh sembilan ribu tujuh ratus sembilan puluh tujuh rupiah). Menghukum Para Tergugat untuk membayar kerugian materiil kepada Penggugat sebesar Rp. 80.899.797,- (delapan puluh juta delapan ratus sembilan puluh sembilan ribu tujuh ratus sembilan puluh tujuh rupiah).

\footnotetext{
18 Ibid, h. 294.

${ }^{19}$ Lihat QS. Al-Isra' ayat 34 yang terjemahannya sebagai berikut:

"Dan janganlah kamu mendekati harta anak yatim, kecuali dengan cara yang lebih baik (bermanfaat) sampai ia dewasa dan penuhilah janji; sesungguhnya janji itu pasti diminta pertanggungan jawabnya."
} 
Menolak gugatan Penggugat selain dan selebihnya. Dalam Rekonvensi Menolak gugatan Penggugat Rekonvensi seluruhnya. Dalam Konvensi dan Rekonvensi Menghukum Para Tergugat Konvensi/Penggugat Rekonvensi untuk membayar semua biaya yang timbul dalam perkara ini yang hingga kini dihitung sebesar Rp.911.000,- (sembilan ratus sebelas ribu rupiah) .

Akibat yang dapat dilihat dari perbuatan tergugat tersebut bahwa tergugat dihukum atas perbuatannya yang terbukti melakukan wanprestasi/ ingkar janji dengan membayar kerugian materiil terhadap penggugat sebesar Rp. 80.899.797 ditambah dengan membayar biaya perkara ini karena kalah dalam berperkara sebesar Rp. 991.000. Jika dijumlahkan adalah sebesar Rp.81.890.797 yang harus ditanggung oleh tergugat untuk membayar akibat yang ditimbulkannya dalam melakukan wanprestasi. Ditambah tergugat telah berdosa dengan melakukan ingkar janji sehingga jika ingin dihapuskannya dosa-dosa tersebut, berdasarkan agama islam dapa melaksanakan apa yang diperintahkan dalam Al-Maidah Ayat 89. Yaitu dengan melakukan memberi makan sepuluh orang miskin, yaitu dari makanan yang biasa diberikan kepada keluarganya, atau membebaskan budak, namun jika tidak sanggup maka hanya melakukan puasa selama 3 hari.

Selain itu akibat hukum dari peristiwa tersebut, yaitu putusnya hubungan hukum atau lenyapnya hubungan hukum antara pihak tergugat dan penggugat karena salah satu pihak telah menodai perjanjian dengan melakukan wanprestasi tersebut. Sehingga hubungan hukum tersebut berakhir dan tergugat wajib membayar sisanya sesuai dengan ganti rugi yang ditentukan oleh hakim. Karena akibat yang ditimbulkan oleh Tergugat disebabkan wanprestasi/ingkar janji sehingga terdapat sanksi yang harus diberikan kepada tergugat serta putusnya hubungan hukum antara penggugat dan tergugat.

\section{PENUTUP}

Dasar Pertimbangan Hakim (Ratio Decidendi) dalam mengabulkan sebagian gugatan dan menolak selebihnya dalam Putusan nomor 1039/Pdt.G/2014/PA.Pbg adalah berdasarkan pertimbangan hakim tentang petitum angka 4 terkait dengan kerugian yang didapat, menurut pendapat penggugat adalah sebesar Rp.88.087.497,- namun majelis hakim berpendapat lain dalam pertimbangan terkait petitum angka 4 yaitu menyatakan para tergugat telah melakukan perbuatan cidera janji/wanprestasi terhadap akad pembiayaan jual beli murabahah dengan kerugian materiil sebesar Rp.80.899.797,- dimana jumlah tersebut dibawah total kerugian yang digugat sebesar Rp.88.087.497,-. Sehingga Petitum angka 5 juga dikabulkan sebagian dengan menghukum para tergugat sebesar Rp.80.899.797,-. Pertimbangan lain terkait dengan petitum angka 2 yaitu permohonan sita jaminan (Conservatoir Beslaag) atas Tanah Hak Milik berikut bangunan Sertipikat Nomor: ---, Luas 427 M2, terletak di Kabupaten Purbalingga, Provinsi Jawa Tengah oleh penggugat yang telah diletakkan hak tanggungan oleh penggugat sendiri sehingga majelis hakim mengeluarkan Putusan Sela nomor: 1039/Pdt.G/2014/PA.Pbg tanggal 7 Januari 2015 yang amarnya menolak permohonan Penggugat untuk meletakkan sita jaminan. Sehingga dapat dikatakan bahwa hakim tidak mengabulkan semua gugatan penggugat. Sehingga amar putusan adalah mengabulkan gugatan penggugat untuk sebagian. Jika 
amar putusan adalah mengabulkan sebagian maka harus dicantumkan pula amar lain yaitu menolak gugatan untuk selebihnya berdasarkan Putusan Mahkamah Agung Nomor 797/K/Sip/1972. Serta Penggugat menerapkan denda dalam akad murabahah dimana denda dilarang oleh Allah kepada orang yang mengalami kesulitan ekonomi.

Akibat hukum yang timbul dalam perkara ini tidak hanya berakibat pada tergugat sebagai pihak yang kalah namun pihak penggugat juga mendapatkan akibat hukum. Akibat hukum dari tergugat yaitu para tergugat berkwajiban membayar ganti rugi kepada penggugat sebesar Rp.80.899.797,- ditambah dengan membayar semua biaya yang timbul dalam perkara tersebut sebesar Rp.911.000,- karena tergugat merupakan pihak yang kalah dalam persidangan. Akibat hukum dari Penggugat adalah putusnya hubungan hukum dengan nasabahnya yaitu tergugat sehingga tidak ada hubungan hukum antara kedua belah pihak namun penggugat berhak menerima ganti rugi dari tergugat.

Berdasarkan kepada permasalahan yang ada dan dikaitkan dengan kesimpulan yang telah dikemukakan di atas, maka dapat saya berikan beberapa saran sebagai berikut: Kepada Masyarakat hendaknya lebih berhati-hati dalam melakukan transaksi khususnya akad murabahah karena akad jual beli yang apabila tidak bisa membayar secara rutin maka dapat dikatakan sebagai ingkar janji dan harus mengganti biaya ganti rugi. Masyarakat dapat menggunakan transaksi lain yang dapat dijadikan alternatif yaitu Akad Mudharabah dan Akad Musyarakah yaitu yang sama-sama merupakan Akad kerjasama yang kemungkinan terjadi perbuatan wanprestasi/ingkar janjinya lebih kecil. Kepada Bank Pembiayaan Rakyat Syariah seharusnya dapat lebih memperhatikan lagi dalam menerapkan denda dalam akad murabahah yang tidak boleh dilakukan. Bank Pembiayaan Rakyat Syariah dapat menggadaikan truck yang dijual sebagai ganti kerugian atas menunggaknya nasabah. Kepada Pemerintah seharusnya dapat menambahkan pasal dalam Undang-Undang Nomor 21 Tahun 2008 tentang Perbankan Syariah atau membuat undang-undang baru terkait dengan transaksi syariah khususnya akad serta akibat yang ditimbulkan jika melanggar akad karena sampai saat ini belum ada pasal dalam undangundang terkait dengan transaksi syariah yang secara langsung mengatur tentang sanksi jika melanggar salah satu akad syariah. Sehingga hakim akan lebih mudah mencari sumber hukum dalam bidang syariah, jika terjadi suatu peristiwa hukum syariah. 


\section{DAFTAR PUSTAKA}

Buku:

Darsono, Ali Sakti, Ascarya, dkk. 2017. Perbankan Syariah di Indonesia: Kelembagaan dan Kebijakan Serta Tantangan ke Depan. Jakarta: Rajawali Pers.

Peter Mahmud Marzuki. 2006. Penelitian Hukum. Jakarta: Prenada Media Kencana.

Soeroso. 2000. Pengantar Ilmu Hukum. Jakarta: Sinar Grafika

Subekti. 1989. Hukum Acara Perdata. Bandung : Binacipta.

Zulkarnaen dan Dewi Mayaningsih. 2017. Hukum Acara Peradilan Agama di Indonesia

(Lengkap dengan Sejarah dan Kontribusi Sistem Hukum terhadap Perkembangan

Lembaga Peradilan Agama di Indonesia). Bandung : Pustaka Setia.

Perundang-undangan

Kitab Undang-Undang Hukum Perdata

Kitab Undang-Undang Hukum Dagang

Undang-Undang Nomor 21 Tahun 2008 tentang Perbankan Syariah

Undang Undang Nomor 1 Tahun 1995 tentang Perseroan Terbatas

Internet/ Media Online:

https://www.eramuslim.com/berita/analisa/dalil-bahwa-syariah-islam-sebagai-

jawabir-penebus-siksa-akhirat-jawazir-pencegah-terjadinya-tindak-kriminal-yang-

baru-terulang-kembali.html diakses pada tanggal 10 oktober 2019.

Putusan Pengadilan:

Putusan Pengadilan Agama Purbalingga Nomor 1039/Pdt.G/2014/PA.Pbg 